\title{
1. The financial system and roots of crisis
}

Financial crises have occurred for centuries, and after the Great Recession of 2008 which began in the United States (US) and spread globally, both economists and policy makers have realized that economically developed countries are not immune from such phenomena. After the Asian financial crisis that began in 1997, much literature was generated which sought to decrease the volatility of capital flows, but in most studies, these short-term flows were seen as problematic only in combination with underdeveloped financial systems. Yet at this point, we have witnessed the final death knell of the efficient-markets hypothesis (according to reasonable economists) which holds that prices immediately reflect all available information. We have also watched a key economic figurehead, former US Federal Reserve Chairman Alan Greenspan, admit that he was wrong in approaching monetary policy from a free market ideology. Free market ideology, in which markets are viewed as self-correcting and symmetric, remains prevalent in the United States, but cracks in the system can no longer be ignored. As history has shown, rather than reaching equilibrium, markets can descend into stagnation without active policy maneuvers. The correct policies are still subjects of sharp debate.

This book seeks to describe and analyze the events, causes, and outcomes of crises from the Great Depression to the Great Recession, unifying a vast amount of literature on each crisis. We start from a general discussion of the global financial system and the roots of crises, both theoretical and empirical. We then discuss crises between 1929 and 2011. We briefly discuss select events before 1929, but focus on the Great Depression and beyond since these crises were created within or bore the current policies and institutions of our current financial system. Our approach differs from what we consider the two leading texts on financial crises (in terms of comprehensive content coverage and analysis), Manias, Panics and Crashes by Kindleberger (1978), ${ }^{1}$ and more recently, This Time is Different, by Reinhart and Rogoff (2009). While Kindleberger discusses major themes in financial crises from the Dutch Tulip Crisis to the Asian financial crisis, and while Reinhart and Rogoff analyze empirically several centuries of crises, we analyze major crises separately to view them in light 
of the scholarly consensus on each crisis and of more recent understanding of financial fragility.

\section{FINANCIAL CRISIS, DEFINED}

First we must agree on a definition for financial crises. We know that we can clearly define a recession in economic terms. Even though there are alternative definitions outlining the time spans in which a downturn occurs, a recession is considered a decline in gross domestic product (GDP) or GDP growth. Financial crises are bigger, confidence-negating episodes. Liquidity may be lost or frozen, in the case of banking crises, or currency may lose its value, in the case of currency crises. At what point does a recession, a credit crunch, an inflationary or deflationary episode, a payment default, or a change in currency value, become a crisis?

The two classic definitions of financial crises, posed by Hyman Minsky (1977) and Charles Kindleberger (1978), make use of the notion of financial fragility. In both definitions, an excessive boom leads to an inevitable crisis or contraction as part of the natural business cycle and the unstable nature of finance. In Minsky's definition, there is a forced liquidation of assets, a credit crunch, and then a sharp drop in asset prices, leading to a depression. A lack of prudence and undue financial fervor (a "mania" in Kindleberger's terms) bring about a financial crisis.

Minsky, whose work was not popularized in the mainstream media until the Great Recession of 2008, after his death, viewed financial markets as essentially fragile and crisis prone, and described three financial postures that the market can take. The first is hedge financing, in which financial institutions have sufficient cash to cover principal and interest on debts. The second is speculative financing, in which institutions can cover interest but not principal; and the third is Ponzi financing, in which financial institutions cannot cover either principal or interest on debts (Minsky 1991; originally in Minsky 1980).

Within Minsky's framework, procyclical credit expansions, or increases in flows of credit in conjunction with an expansionary period during economic growth, can reverse during contraction and lead to financial fragility. Finance is stable when the market is successfully operated, and unstable when events in an uncertain environment push the market into a precarious position. The increase in the number of financial transactions and the speed at which they have been performed in the past 30 years have demonstrated the fragile nature of finance, as the world economy has of late spent a great deal of time in speculative and Ponzi mode.

In his original work, Kindleberger (1978) first describes the beginning 
of a crisis as a speculative mania, of which there are two stages. The first stage of a mania is a response to an external shock, such as war; while the second is related to profit seeking. Secondly, credit expansion aggravates the mania, and over time, expectations reverse. Kindleberger dubs the sequence "biological in its regularity." Financial distress may then develop into a crisis, triggered by a causa proxima, any event that causes investors to sell. Hence a crash or panic may ensue. Unlucky countries engaged in financial activity with the country in turmoil may experience contagion of the crisis. A wide range of policy responses, from simply doing nothing to enforcing bank holidays, to using a domestic or international lender of last resort, may be and have been used.

However, researchers have also used various quantitative measures to determine crises. Carmen Reinhart and Kenneth Rogoff, American economists who have written extensively on crises and other macroeconomic events, construct a database that extends over a period of eight centuries and provides indicators on the existing financial environment (Reinhart and Rogoff 2009). Reinhart and Rogoff define inflation crises as inflationary episodes of greater than 20 percent per year, currency crises as exchange rate depreciations over 15 percent per year, banking crises as events in which important or besieged (run upon) banks submit to government takeovers, sovereign default as failure to meet a payment on the due date, and domestic debt crises as situations where payments cannot be met or bank deposits are frozen or forced to convert to local currency.

As a result of their analysis, themes emerge from descriptive and econometric analysis. Reinhart and Rogoff find that almost all countries experience serial default during the intermediate stages of economic development, and these occurrences are often accompanied by high inflation, currency crashes, and devaluation. The authors also find that periods of extensive financial opening are often followed by domestic banking crises. Looking at data on crises between 1800 and 2006, Reinhart and Rogoff find that there are five long periods in which countries are in default or financial restructuring. These conclusions are in line with the idea that finance is generally unstable, and that increased instability leads to crisis.

Less comprehensive definitions also exist. Carron and Friedman (1982) define a financial crisis from a microeconomic perspective, in which some borrowers face a risk premium arising from unrelated financial developments, which may induce solvency and liquidity problems. This causes a banking crisis. Bordo and Wheelock (1998) also define a financial crisis as a banking panic. These definitions, however, do not account for currency crises. At the opposite end of the spectrum, Andrade and Teles (2004) define a financial crisis from a macroeconomic perspective, in which 
there is a shift from a good equilibrium with low country risk to a bad equilibrium with high country risk.

Additional crises have been defined as periods in which there is a general consensus that risk has dramatically increased. For example, although financial fragility in the Southeast Asian countries had increased leading up to the Asian financial crisis, a crisis situation was not recognized until a single event occurred: the devaluation of the Thai baht on July 2, 1997 (a causa proxima); the causa proxima date of a crisis is a definition that researchers like Johnson and Mitton (2001) have used. In this book, we define crises in terms of the consensus starting dates while also providing more specific economic evidence of financial decline, in an attempt to reconcile the technical with the popular view.

\section{THE CONTEXT OF MODERN CRISES}

Major crises have occurred sporadically since the Dutch Tulip Crisis in 1637 , but became increasingly global and closer together as the twentieth century approached. Crises moved even closer together at the end of the twentieth century. This is in part due to normal economic expansion and growth, and along with it, rapid changes in production technologies. However, speculative investment sometimes accompanied real expansion, bringing about crises. The major reason for the increase in the occurrence of financial crises at the end of the twentieth century is the immense growth and liberalization of finance, which began with the breakdown of the Bretton Woods system that was constructed in the 1940s, the spread of eurocurrency markets in the 1960s, and the rise of portfolio investment in the 1980s (D'Arista 2002), which are discussed in later chapters.

The US political economy of the 1970s in particular aligned the interests of the banking sector with those of the political arena. This is because the US played a large role in the global economy and led both deregulation and bank standardization. On the one hand, politicians faced the threat of a loss of competition, and on the other, they feared the consequences of a lack of regulation. The relatively recent high-level development of finance has, since then, been a balancing act between the two specters.

The debate over fiscal spending or prudence during crisis, and the beginning of the modern financial architecture, has its roots in the Great Depression. Although banking crises and asset price bubbles were not unique throughout history, the Great Depression was so severe that widely accepted economic policy responses at the time failed to ameliorate the descent into economy-wide failure. New policies, categorized as the "First New Deal," were tried and failed, until at last government interven- 
tion in public assistance, labor, and industrial regulation put the economy on the track to recovery (Bordo et al. 1998). The powerful insights of Keynesian theory were also brought to light during the later period of the Great Depression, and underscored an expanded role for government intervention. Keynesian perspectives dominated economic thought for some time thereafter, and even after their demise in the 1970s, they have been revived to a large extent today, due to desperate measures undertaken during the Great Recession of 2008.

Of equal importance, the transition from the gold standard, destroyed once and for all during the Great Depression, to pegged exchange rates under the Bretton Woods System created in 1944, established the US dollar (at first tied to gold, later used alone) as the international reserve currency. World leaders set up an adjustable peg system of currencies fixed to the dollar, which was in turn exchangeable for gold (Bordo and Eichengreen 1993). These new global monetary structural changes ushered in years of relative financial stability. After the ravages of the Great Depression and World War II, global financial security was greatly desired. And global financial security was indeed gained, in a period of relative peace, until the 1960s. The lasting element of the Bretton Woods architecture was, and remains, the centrality of the US dollar.

The Bretton Woods meeting was truly singular in that it represented a major global effort to establish monetary and financial rules, for the sake of both stabilizing the world economy and enhancing trade and financial relations. Due to fixed exchange rate regimes, inflation was maintained in most countries at low levels. International monetary cooperation, in conjunction with existing capital controls, brought about a period of calm in the global economy. Pegging currencies to the dollar secured US global economic hegemony through the present day, and has had a lasting impact on the dynamics of international financial power and the anatomy of financial crises down the line. Financial and ideological power was concentrated in the US, has influenced patterns of global trade and investment, and produced directives to developing countries for proper measures for economic development. The historical Bretton Woods meeting also brought into existence international financial and monitoring institutions, namely the International Monetary Fund (IMF) and the World Bank. ${ }^{2}$

The second half of the Bretton Woods regime, the 1960s, saw the rise of eurocurrencies, which are deposits located in banks outside the home country. The use of eurocurrencies allowed domestic banks to bypass capital controls in international lending. Eurocurrencies also allowed banks to avert domestic reserve requirements, deposit insurance, interest rate ceilings, and quantitative controls on credit growth (D'Arista 2002). Due to an increase in popularity, eurodollars began to affect countries' 
domestic balance of payments after a period of only a few years, and by the late 1960s the US Federal Reserve began to loosen requirements of domestic lending in order to compete with eurocurrencies, ushering in a period of financial liberalization in the 1970s.

Although Bretton Woods institutions remain in the form of the World Bank and IMF, an important feature of the Bretton Woods exchange system was shattered unilaterally in 1971 by US President Nixon, who ended the dollar's convertibility to gold. Nixon closed the "gold window" due to the United States' perpetual balance-of-payments deficits resulting largely from engagement in the Vietnam War, which had greatly reduced the supply of gold reserves (Bordo 2008). This led to the return of inflation and monetary imbalances and, coupled with capital account liberalization in the early 1970s, signaled the prospective return of financial crises. The dollar became the de facto reserve currency, without a commodity anchor.

A vigorous rise in oil prices in the 1970s caused a global recession, and the recycled petrodollars that had been lent in force to developing nations in Asia, Latin America, and Africa during this period led to a chain of banking and sovereign debt crises years later (Reinhart and Rogoff 2009). Both governments and commercial banks lent exorbitant amounts to developing nations to finance their oil imports, setting the stage for the debt crises of the 1980s. Eurocurrency markets spread through the 1970s, in large part due to petrodollar lending, and came into competition with more restricted commercial bank lending in the 1980s. Financial liberalization continued, particularly with the rapid expansion of portfolio investment in this same period. This greatly increased capital mobility and the quantity of cross-border transactions in bonds and equities (D'Arista 2002).

Due to a global environment of increased financial liberalization, the 1980s saw the emergence of debt default crises in Latin America as banks refused to continue financing developing countries' interest payments. Crises then came closer together, with the European Exchange Rate Mechanism Crisis and Nordic banking crises of the late 1980s and early 1990s. Policy conditions imposed by the IMF on developing and developed countries alike in exchange for emergency loans required financial austerity and later came under sharp criticism. The "Washington Consensus," a set of policies so dubbed in 1989 and pushed forward by the IMF for countries enmeshed in crisis, incorporated two of the policy prescriptions that had so emphatically failed in the immediate aftermath of the Great Depression: fiscal policy discipline and expansion of the tax base. The recommendations also included policies that increased the level of risk and exposure to foreign and domestic shocks, such as privatization and trade liberalization. 
The prolonged Japanese real estate bust occurred in 1992, followed on its heels by the Mexican peso crisis. Then, just as the 1990s were roaring in the US, the rest of the world went into crisis, hitting the Southeast Asian tigers, Russia, Brazil, and Argentina. Clearly, something was amiss in the global financial architecture. Even the genius mathematical models constructed for long-term credit management under the supervision of Nobel laureates Myron Scholes and Robert Merton failed to decode the complex movements of international finance.

After the Asian financial crisis of 1997, some economists recognized that the collapse of Bretton Woods had led to global financial and monetary instability. The long series of crises after 1971 that came closer together indicated that there may be something fundamentally volatile about the modern financial architecture. The longed-for era of stability under the Bretton Woods system could not be forgotten, and some called for eliminating what has been dubbed the "dollar standard," in which the dollar gained inherent value with the closing of the gold window, and replacing it with a more globally oriented basis of monetary transactions. Also due to short-term capital reversals that occurred during the Asian crisis, the wave of thinking that led to large-scale capital account liberalizations - that is, the Washington Consensus - has become less prominent, if not outmoded in some circles.

The crisis that began in the US in 2007 and 2008 spread quickly across the globe. Because of the centrality of the US economy in terms of both finance and trade, other economies in Europe, Asia, Latin America, and elsewhere were all affected. Those in many strata of income suffered real losses, as individuals directly involved in finance experienced stock market and asset declines, as currencies were devalued, and as export laborers and migrant workers lost jobs.

Although a second radical global change toward economic stability, another "Bretton Woods," is unlikely to occur in the near future, it has been recognized that, at least, more sophisticated and coordinated monitoring of the world economy must take place. It behooves us to examine in detail the panoply of crises that have occurred since 1929, in order to better understand the economic and financial context in which these crises arose, and how they were affected by policies designed, for better or worse, to cushion their impact. With international cooperation and greater understanding of historical missteps, we hold the optimistic view that solutions toward stability can be formulated and implemented. 


\section{GLOBAL FINANCE TODAY}

We next look at the global financial architecture as it stands today. Since there are too many details to discuss all aspects of the global financial architecture, we focus on a few features that affect capital flow and regulation and currency volatility. These features include:

\section{Existence of a Global Reserve Currency Hegemony Comprised of Limited Countries or Regions}

Currently, the dollar is the most widely used global reserve currency. The willingness of foreign governments to hold dollar-denominated foreign currency securities has allowed the US to operate under prodigious national and trade deficits. Because of this, the US has had de facto unlimited credit to purchase goods and services from abroad. Some scholars and financiers, such as George Soros (see Chinn and Frankel 2008; Conway 2008) predicted that the euro would overtake the dollar as the largest international reserve currency (although this has been a subject of debate due to Europe's deep involvement in the global crisis of 2008), but this may simply shift the balance of financial and purchasing power to another region, and concentrated reserve currency power will continue to exacerbate trade and financial imbalances. A better solution would be what Frankel (2009) promotes as "a multiple international currency system." In this type of system, the dollar would lose its dominance as a global reserve currency and other currencies, such as the euro, yen, and in time, the renminbi, could join the dollar as important stores of international reserves.

An associated problem is the issue of "original sin," in which emerging markets in particular cannot borrow abroad in their own currency. Therefore, when these countries accumulate a net debt, they develop an aggregate currency mismatch on their balance sheets. As Eichengreen et al. (2004) show, "original sin" has important stability and economic implications in terms of both policies and outcomes. Developing country domestic policies cannot be used wholesale to encourage growth within the country; many of the policies must be oriented toward servicing the international debt and maintaining a stable exchange rate. Debt denominated in foreign currency, in emerging markets with pegged exchange rates, requires developing countries to balance foreign currency borrowing with the trade deficit and foreign currency reserves in order to maintain a pegged exchange rate. Foreign exchange reserves are necessary to sell in order to uphold the value of the domestic currency when exports decline or currency demand falls. Balance sheet crises can occur, either from holding debt in short-term foreign currency, or from a currency mismatch in corpo- 
Table 1.1 International bonded debt, by country groups and currencies, 1991-2001

\begin{tabular}{lccc}
\hline & $\begin{array}{c}\text { Total debt } \\
\text { instruments } \\
\text { issued by } \\
\text { residents (\%) }\end{array}$ & $\begin{array}{c}\text { Total debt } \\
\text { instruments issued } \\
\text { by residents in } \\
\text { own currency (\%) }\end{array}$ & $\begin{array}{c}\text { Total debt } \\
\text { instruments } \\
\text { issued in groups' } \\
\text { currency (\%) }\end{array}$ \\
\hline $\begin{array}{l}\text { Major financial centers } \\
\text { Eurozone }\end{array}$ & 45 & 61 & 68 \\
$\begin{array}{l}\text { Other developed } \\
\quad \text { countries }\end{array}$ & 83 & 37 & 30 \\
$\begin{array}{l}\text { Developing countries } \\
\text { International } \\
\quad \text { organizations }\end{array}$ & 8 & 2 & 1 \\
ECU & 7 & 0 & 1 \\
\hline
\end{tabular}

Note: Major financial centers include the US, Japan, the United Kingdom, and Switzerland.

Source: Eichengreen et al. (2004), Bank for International Settlements.

rate balance sheets (Jeanne and Zettelmeyer 2004). The label "original sin" is appropriate since denominating debt in foreign currency can cause many other problems originating from the currency regime.

As a mirror image of the problem, US data from 2001 show that developed countries are more often willing to expose themselves to developing country credit risk rather than developing country currency risk, which may be more financially fragile. Table 1.1 describes total debt issued in countries' own currencies.

As seen in Table 1.1, the major financial centers are able to issue much or most of their debt in their own currencies, while other countries do not share that privilege. If developing countries experience "original sin," developed countries encourage the sinners.

\section{Persistence of Unregulated International Capital Flows}

Some international capital flows remain unregulated or less regulated than those under banking supervision. These consist of capital flowing through the carry trade market, in which investors borrow in low-yielding currencies and invest in high-yielding currencies. Although hedge funds must now be registered with the Securities and Exchange Commssion (SEC) in the US and in Europe, these and other actors, counting on interest rate differentials and exchange rate appreciation, have played a large role 
in procyclical carry trades (D'Arista and Griffith-Jones 2009). Carry trades, during downturns as yields reverse, can create deepening currency mismatches that necessitate international intervention, as in the case of Iceland and Hungary in 2008. Eurocurrency markets, which consist of dollar or other deposits held by banks in foreign countries, were subjected to some regulation after Basel I, but continue to evade regulation, and are the main suppliers of funds for the carry trade (D'Arista 2006). American and European regulation implemented in the wake of the Great Recession has not put specific controls on the eurocurrency market.

These evasive capital flows are dangerous. Trade in goods and trade in capital are not equal (Bhagwati 1998). The argument for free trade does not extend to free capital; restricted capital mobility is not tantamount to protectionism. This is because free capital flows can experience sharp reversals, harming economies in their wake. Because of this, some countries have instituted capital controls to curb this maleffect of international financial flows.

\section{Mix of Capital Control Regimes}

Countries' control over capital inflows and outflows vary across the world, from capital openness to tight capital control. Capital controls create stability by preventing the flow of real and financial assets as recorded in the capital account in the balance of payments. Such controls can take the form of taxes, quantity or price controls on capital inflows or outflows, or restrictions on trade in assets abroad. These were first used on a larger scale by the belligerents beginning during World War I, restricting capital outflows, in order to keep capital in the domestic economy for taxation purposes (Neely 1999).

Although throughout the 1990s, financial openness was encouraged, studies have shown that financial openness has mixed effects. After the Asian financial crisis, China was lauded for maintaining capital controls, which helped the country to evade accelerating capital reversals, and capital controls once again were back in vogue. Later research, such as that of Chinn and Ito (2005), finds that financial openness is beneficial only in countries above a particular level of institutional development. Indeed, the Great Recession has shown that capital controls may be applicable to countries with an even higher level of institutional development, since without capital controls, contagion of declining assets can quickly spread to foreign-investing countries.

Edwards (2005) creates an index of capital controls to determine countries' vulnerability to and depth of financial crises, looking at crises that manifest themselves in sudden stops of capital inflows and current 
account reversals. He finds that openness may worsen a financial crisis once it has begun. Other authors, such as Chang and Velasco (1998) and Williamson and Mahar (1998), find that financial openness may also increase vulnerability to crises.

\section{Implementation of Basel I, Basel II, and (soon) Basel III}

Basel I and II set standards for banks around the world. Basel I was created in 1988, Basel II in 2004, in order to improve and coordinate banking supervision, regulation, and capital adequacy requirements across countries (Balin 2008). The accords are not enforced by any supranational body, but are guidelines for best banking practices. The Group of Ten (G-10) comprised the Basel Committee during the first round of Basel guidelines, and Basel I was considered applicable mainly to these developed countries.

Basel I protected against banking risk, and was not drawn up to prevent other sources of systemic risk created by lack of diversification or market risk (Balin 2008). Basel I grouped assets into categories according to credit risk, requiring banks to hold minimum capital levels according to their risk levels (Elizalde 2007). Most Basel Committee members implemented Basel I by 1992 .

Banks found loopholes around Basel I, and for this reason, and because of the need to increase coverage of systemic risk and improve applications to developing countries, Basel II was created. Basel II created three pillars to expand on Basel I in order to cover these gaps. These pillars were: Pillar 1, capital requirements; Pillar 2, supervisory review; and Pillar 3, market discipline. The latter two are the newer components, while Pillar 1, which largely comprised Basel I, expanded risk sensitivity. Pillars 2 and 3 are less extensive than Pillar 1 and have been largely left to the discretion of supervision of national officials (Elizalde 2007). Basel III was put forward in June 2011 to improve systemic banking oversight, as well as to improve banks' risk management and transparency (BIS 2011). It is comprised of the same three pillars as in Basel II. Box 1.1 illustrates the Basel III Three-Pillar model.

Due to shortcomings of the previous Basel Models, Basel III was created to set up stronger requirements for banks. These include ensuring better quality and transparency of the capital base, in particular since the crisis revealed the inconsistency of capital definitions across regions and a lack of full disclosure of the capital base (BIS 2010). They also include enhancing risk coverage to raise capital requirements for trading and complex securitizations using a stressed value-at-risk capital requirement, since the Great Recession revealed that exposure to on- and off-balance sheet risk was not captured. Basel III also seeks to supplement the risk-based capital 


\section{BOX 1.1 BASEL III THREE-PILLAR MODEL}

\section{Pillar I Capital Requirements}

Capital:

- Quality and level of capital.

- Greater focus on common equity. The minimum will be raised to $4.5 \%$ of risk-weighted assets, after deductions.

- Capital loss absorption at the point of non-viability.

- Contractual terms of capital instruments will include a clause that allows - at the discretion of the relevant authority - write-off or conversion to common shares if the bank is judged to be non-viable. This principle increases the contribution of the private sector to resolving future banking crises and thereby reduces moral hazard.

- Capital conservation buffer.

- Comprising common equity of $2.5 \%$ of risk-weighted assets, bringing the total common equity standard to $7 \%$. Constraint on a bank's discretionary distributions will be imposed when banks fall into the buffer range.

- Countercyclical buffer.

- Imposed within a range of $0-2.5 \%$ comprising common equity, when authorities judge credit growth is resulting in an unacceptable build-up of systematic risk.

Risk coverage:

- Securitizations.

- Strengthens the capital treatment for certain complex securitisations. Requires banks to conduct more rigorous credit analyses of externally rated securitization exposures.

- Trading book.

- Significantly higher capital for trading and derivatives activities, as well as complex securitizations held in the trading book. Introduction of a stressed value-at-risk framework to help mitigate procyclicality. A capital charge for incremental risk that estimates the default and migration risks of unsecuritized credit products and takes liquidity into account.

- Counterparty credit risk.

- Substantial strengthening of the counterparty credit risk framework. Includes: more stringent requirements for measuring exposure; capital incentives for banks to use central counterparties for derivatives; and higher capital for inter-financial sector exposures.

- Bank exposures to central counterparties (CCPs).

- The Committee has proposed that trade exposures to a qualifying CCP will receive a $2 \%$ risk weight and default fund exposures to a qualifying CCP will be capitalized according to a risk-based method that consistently and simply estimates risk arising from such default fund. 
Containing leverage:

- Leverage ratio.

- A non-risk-based leverage ratio that includes off-balance sheet exposures will serve as a backstop to the risk-based capital requirement. Also helps contain system-wide build-up of leverage.

\section{Pillar II Risk Management and Supervision}

- Supplemental Pillar 2 requirements.

- Address firm-wide governance and risk management; capturing the risk of off-balance sheet exposures and securitization activities; managing risk concentrations; providing incentives for banks to better manage risk and returns over the long term; sound compensation practices; valuation practices; stress testing; accounting standards for financial instruments; corporate governance; and supervisory colleges.

\section{Pillar III Market Discipline}

- Revised Pillar 3 disclosures requirements.

- The requirements introduced relate to securitization exposures and sponsorship of off-balance sheet vehicles. Enhanced disclosures on the detail of the components of regulatory capital and their reconciliation to the reported accounts will be required, including a comprehensive explanation of how a bank calculates its regulatory capital ratios.

Source: Bank for International Settlements (2012).

requirement with a leverage ratio, which would constrain leverage and reduce the risk created by deleveraging processes. Procyclicality has also been addressed in the hopes of dampening cyclical amplifications of the minimum capital requirement and preventing excess credit growth. Finally, Basel III seeks to address systemic risk by increasing capital requirements for trading activities and inter-financial sector exposures and by using central counterparties for over-the-counter derivatives.

\section{Large, Unwieldy Financial-Banking Institutions}

Policies that emerged in the 1980s and 1990s in developed countries allowed commercial banks to merge with investment banks, securities firms, and insurance companies. This resulted in the rise of mammoth financial institutions that lacked transparency and appropriate regulation. This, coupled with large, procyclical bonuses in the banking sector and 
the lack of a global financial regulator resulted in the Great Recession of 2008.

Simon Johnson (2009b) of Massachusetts Institute of Technology (MIT) and other major economists have dubbed the new financial organizations as "too big to fail." "Too big to fail" creates moral hazard, in which banking managers take excessive risks because they assume the government will bail them out should the risky investments fail. Buiter (2009) notes that although firms can be closely interconnected, it is large firms that threaten the stability of financial systems. These firms can become so large that they no longer exploit economies of scale and scope, but lose control over their own organizational activities and efficiency. Bailouts based on "too big to fail" were eliminated in the US DoddFrank Act of 2010 but specific legislation preventing the build-up of large financial institutions was not part of the bill, and was left to the discretion of the Financial Stability Oversight Council.

\section{Procyclical and Short-Term Risk Measurement}

The Great Recession of 2008 showed that risk modeling can be so deeply flawed as to allow banking officials to overlook entrenched banking instability. D'Arista and Griffith-Jones (2009) point out that the value-at-risk measurement is procyclical, and additional, non-cyclical measures of risk must be used. The value-at-risk (VaR) measurement provides the probability that an asset or bundle of assets will decline by a particular amount over a given time period. Capital requirements given by VaR are inherently procyclical, since banks experience more losses during recessions than during booms, decreasing the lending capacity of the institution. Dodd-Frank and Basel III mandated changes that require countercyclical capital requirements (Kowalik 2011). The Basel III changes designate a buffer of $0-2.5$ percent above the minimum capital requirements, while Dodd-Frank also includes countercyclical capital requirements and requirements that holding companies assist subsidiaries of insured depository institutions.

These are the major aspects of the current global financial architecture. As noted above, many changes within the world economic structure still need to be made, yet regulatory and institutional change has been ongoing. It will become apparent that institutional change in the face of financial instability is the only consistent feature of the global financial architecture. 


\section{STRUCTURE OF THE BOOK}

Having looked at aspects of the financial architecture and at the general context of modern crises, we are now ready to look at individual crises themselves. In order to do this, we discuss crises by time period. Some time periods are long and are occupied by one large crisis, such as the Great Depression, while other time periods are relatively short and encompass several crises, such as the early 1990s in which several countries experienced economic reversals.

We move through the twentieth and early twenty-first centuries in chronological order. Chapter 2 analyzes the Great Depression and its aftermath, in which many economies struggled to recover. We first touch upon the political economy before 1929, discussing the crisis of 1907 and the destabilizing influence of World War I, then discuss at length the causes and economic debate surrounding the Great Depression. We look at the transmission of the Great Depression through the mechanism of the gold standard, which was once and for all abandoned during this period. Finally, we discuss policies implemented in the US and Europe to overcome the depression, and the impact of World War II on the global economy.

Chapter 3 examines the 1950s through 1970s, under the Bretton Woods system, which experienced a relatively low level of crises with increasing financial instability. We look at the factors that allowed for this relative stability and debate its sustainability. Although the 1950s brought on a period of general financial stability, increasingly, a high level of global coordination was required in the 1960 s as imbalances threatened to undermine the system due to increasing pressures on the US balance of payments. The US could not maintain its level of spending while upholding credibility in the dollar-gold standard. Because of the United States' growing current account deficit, the Bretton Woods dollar-gold parity was unsustainable and unilaterally canceled in the 1970s, which brought about great changes in the global financial architecture. The end of Bretton Woods coincided with unrest in the Middle East and a consequential large movement of capital from both oil-rich and developed countries to oil-poor developing nations, which set the stage for increased financial liberalization that allowed such transfers of funds.

The expansion of financial instruments and global economic and political forces gave rise to the 1980s' emerging markets debt default crises when the indebted Latin American countries found themselves unable to repay loans at higher interest rates, the subject of Chapter 4. In this chapter, we examine the processes at work in these crises, both from the prevailing perspective at the time of the crisis, as well as from a historical perspective of sovereign debt crises. 
Much to the chagrin of the developed world, crises in advanced countries were not far ahead. The Nordic crises, the Exchange Rate Mechanism crisis, and the Japanese crisis in the early 1990s are examined in Chapter 5. The Nordic crises began at the end of the 1980s and were exacerbated by the European Exchange Rate Mechanism crisis of 1992. The Japanese crisis began with the bursting of the asset bubble at the end of the 1980s, extended through the early 1990s, and culminated in a larger systemic crisis in 1997.

The mid- and late 1990s saw a return to emerging markets crises, with the Mexican peso crisis and the Asian financial crisis, the focus of Chapter 6. The Asian financial crisis was a shock to those who had considered the Southeast Asian tigers to be growth machines, and threatened global contagion. Global contagion indeed arose in Russia and Brazil. Chapter 7 elaborates on the Russian, Brazilian, and Argentine financial crises, all connected to the Asian financial crisis but also to varying degrees products of domestic economic shortcomings.

Chapter 8 covers the Great Recession of the late 2000s. We study the reasons for the initiation and spread of the crisis, as well as outcomes and changes in the global economy. Chapter 9 covers global imbalances and shows how some economists have referenced these imbalances in discussing the reasons for the rise of financial crises.

Finally, as an appeal to concerned individuals, Chapter 10 looks at policy recommendations for preventing future crises. Some of the recommendations resulted from the Asian financial crisis and endured, while others have arisen from the most recent international crisis. We study the viability of these proposals and the implications for the future global financial architecture. ${ }^{3}$

\section{NOTES}

1. Most recently published in 2005 with Robert Aliber.

2. At the time, the World Bank was known as the International Bank for Reconstruction and Development.

3. The author would like to thank Jane d'Arista and an anonymous referee for their invaluable comments on the manuscript. 